\title{
Long-term follow-up failed to detect in vitro transmission of full-length porcine endogenous retroviruses from specific pathogen-free pig islets to human cells
}

\author{
B. Clémenceau, D. Jégou, L.Martignat, P. Saï \\ Cellular and Molecular Immuno-Endocrinology, INRA/ENVN/University, Nantes cedex, France
}

\section{Abstract}

Aims/hypothesis. Islets from specific pathogen-free (SPF) pigs could prevent the transmission of conventional zoonosis, but not endogenous retroviruses (PERV), from pigs to diabetic patients. We previously reported that the pancreas showed the lowest expression of PERV mRNA among pig tissues intended for grafting. This study aimed to determine whether PERV from pig islets infect human cells during co-incubation.

Methods. Human cells (including highly PERV-sensitive 293 cells) were incubated with SPF pig islet cells under conditions designed to increase contact (a high islet to human cell ratio, extended period of coculture, and repeated contacts). PK15 and G2 retrovirus-producing pig cells were used in place of islet cells as "positive infection controls". Infection of human cells was monitored on cellular extracts and supernatants by PCR or long PCR, and RT-PCR or long RT-PCR, to detect PERV DNA and mRNA, respectively. Reverse-transcriptase activity was monitored by PERT.

Results. Despite the presence of all PERV sequences in pig islet cells, including full-length inserts, no DNA or RNA for gag, pol, and the 3 env sub-types were detected in any human cell line or blood mono- nuclear cells incubated with pig islet cells, during an 18-week follow-up period. No PERV sequences or RT activity were detected in supernatants. PERV signals were negative even when the pig islet to human cell ratio was increased to $100: 1$, the time of co-culture was extended to 5 days and two sequential co-incubations were done. By contrast, all PERV DNA and mRNA were detected in all human cells co-incubated with PK15 or G2 cells. Depending on human cell types, productive or non-productive infections were obtained: full-length PERV RNA and RT activity in supernatants were detected or not; and PERV sequences to previously unexposed human cells by PERV-infected human cells were transmitted or not. Some human cells were not productively infected by PK15 cells but became productively infected after co-incubation with PERV-infected 293 cells.

Conclusion/interpretation. SPF pig islet cells, even with PERV inserts and transcripts, have very little probability of transmitting PERV to human cells during co-incubation. The sensitivity of human cells to stable and productive infection by PERV depends on the cell type. Human adaptation of PERV was observed. [Diabetologia (2001) 44: 2044-2055]

Keywords Xenograft, pig endogenous retrovirus, pig islet cell, specific pathogen-free pig, infection assay.
Received: 18 May 2011 and in revised form: 12 July 2001

Corresponding author: L. Martignat, Cellular and Molecular Immuno-Endocrinology, INRA/ENVN/University, Atlanpole, La Chantrerie, BP 40706, 44307 Nantes cedex 3, France, e-mail: Martignat@vet-nantes.fr
Abbreviations: SPF, Specific pathogen-free; bp base pair; COII, cytochrome oxidase subunit II; mt DNA mitochondrial DNA; PBMC, peripheral blood mononuclear cells; PCR, polymerase chain reaction; PERV, porcine endogenous retrovirus; RT, reverse transcriptase; PERT, product-enhanced reverse transcriptase test 
The use of pig islets for grafts in diabetic patients has been investigated [1]. There is a risk of transmitting infectious agents from pig to man. Our group is concerned with pig islet xenografts [2-8], and in studying the risk of conventional zoonosis we isolated islets from pigs raised in specific pathogen-free (SPF) conditions [2]. Overall, there is a risk of transmission of porcine endogenous retroviruses (PERV) [9-15]. Depending on the env genes involved in cell tropism, 3 PERV have been described - A, B and C $[11,12,14$, 16-19]. Corresponding mRNA have been identified in pig cell lines or tissues $[6,12,18,19]$. Gag and reverse-transcriptase (RT) pol genes of these three PERV sub-types are closely related $[12,19]$. All pigs tested expressed PERV mRNA [11, 12, 17, 20], including SPF pigs $[6,18]$. These sequences are able to produce type $\mathrm{C}$ particles, whose release by pig cell lines [21-23] and primary cells $[17,20]$ has been described. Full-length endogenous retroviral genome with env gene polymorphism has shown up in several pig strains $[12,14]$, including SPF pigs [18]. Thus, the use of SPF pigs does not eliminate the risk of transmission of PERV to xenograft recipients.

The ability of PERV produced by PK-15 pig cells or pig primary cell cultures to infect human cells in vitro has been documented [11, 16, 17, 19, 20, 24, 25]. By contrast, porcine foetal neuronal cells were not able to infect human cells [26]. The use of murine retroviral vectors carrying porcine PERV env genes strongly suggests that $e n v-A$ and $e n v-B$ have a more potent tropism for human cells in vitro than does env-C [19]. Serial passages of PERV through a human cell line produced retroviruses with higher infectious potency for human cells than the initial virus [24]. The actual risk of infection during pig tissue xenografts can only be accurately evaluated by long-term in vivo experiments. To date, investigations in baboons [27] and patients transplanted or dialysed extracorporeally with pig tissues [28-31] have failed to detect transmission of pig retroviruses. However, recent studies have indicated that PERV could be transmitted to mice after pig islet xenografts [25, 32], although contradictory results have been reported [33].

In vitro studies are needed to clarify the precise conditions leading to PERV infection of human cells. Furthermore, the risk of transmitting PERV needs to be evaluated not only in general, i.e. independently of the type of pig tissue to be grafted, but also specifically for a given tissue. The risk of transmission could depend on viral load, as has been shown to be the case in other retroviral infections [34]. Our previous comparison of the expression of PERV mRNA in different pig tissues intended for grafting [6] revealed that the pancreas expressed the lowest levels of PERV mRNA.

The present study investigated whether SPF pig islets transmit PERV sequences to human cells during in vitro co-incubations, under conditions designed to increase the probability of contact. Pig islet and human cell co-incubations were compared to those with PERV-producing pig cell lines, using a panel of human cells, including highly PERV-sensitive 293 cells. Infection of human cells was monitored by PCR and RT-PCR, with long-term follow-up and frequent analyses of both cellular extracts and supernatants, to detect PERV DNA and RNA for gag, pol and the 3 env sub-types. Long PCR and RT-PCR were done for the first time to detect full-length PERV proviruses and genomic RNA, respectively. Product enhanced reverse transcriptase test (PERT) was used to detect RT activity in supernatants.

\section{Materials and methods}

\section{Specific pathogen-free (SPF) pigs: isolation of pig islet cells}

Large white SPF pigs (80-120 kg), aged 20 weeks, from our stock were used as previously described [35]. Pancreases were removed under sterile conditions, soaked in betadine solution, immediately inflated with $100 \mathrm{ml}$ ice-cold sterile modified University of Wisconsin (mUW) solution and transported in mUW. Pancreases were then inflated again with $0.5 \mathrm{ml} / \mathrm{g}$ of mUW solution containing $2 \mathrm{mg} / \mathrm{ml}$ Liberase (Roche Diagnostics, Meylan, France) and placed in a digestion chamber filled with mUW solution kept at $36^{\circ} \mathrm{C}$. Crude islets were pelleted by centrifugation, suspended in mUW and purified on continuous Optiprep gradient (Life International Technology, CergyPontoise, France) with a COBE 2991 processor. Islet purity, as assessed by dithizone staining, exceeded $90 \%$. This isolation provided islets capable of reacting to nutriments, hormones and neuromediators [3]. Islets were treated with EDTA and dispase to obtain islet cell suspensions. Islet cells were numerated and suspended in Ham's F10 medium $(5.5 \mathrm{mmol} / \mathrm{l}$ glucose) (Biomédia, Boussens, France) supplemented with $2 \%$ Ultroser (BioSepra SA, Villeneuve la Garenne, France).

\section{Porcine retrovirus-producing cell lines and human target cells}

PERV-producing PK15 and G2 pig cells were provided by Dr E. Albina (AFSSA, Ploufragan, France) and Dr B. Kaeffer (INRA, Nantes, France), respectively. RPJ kidney-derived cells, and aortic endothelial pig cell lines were provided by B. Kaeffer. Cells were cultured in Modified Eagle's Medium (MEM) containing 10\% fetal calf serum (FCS), $2 \mathrm{mmol} / 1 \mathrm{glu}-$ tamine and $1 \mathrm{mmol} / \mathrm{l}$ sodium pyruvate (Eurobio, Les Ulis, France).

The following human cell lines (ATCC) were maintained in RPMI 1640 medium, supplemented as described above: HT-29 colon adenocarcinoma (HTB-38), Capan-1 pancreas adenocarcinoma (HTB-79), K-562 erythroleukemia (CCL-243), Molt-4 (CRL-1582). and Jurkat (TIB-152) leukaemia T cells. Human PHA-activated peripheral blood mononuclear cells (PBMC) (provided by Dr M. Bonneville, Nantes, France) were kept in RPMI 1640, supplemented with $20 \mathrm{U} / \mathrm{ml}$ human purified interleukin-2 (Roche Diagnostics, Meylan, France), $25 \mathrm{mmol} / \mathrm{l} \mathrm{HEPES}$ buffer, $10 \% \mathrm{FCS}, 2 \mathrm{mmol} / \mathrm{l}$ glutamine and 
Table 1. Primer pairs for PCR amplification of PERV, porcine circovirus, and porcine mitochondrial DNA (mtDNA)

\begin{tabular}{|c|c|c|c|}
\hline Region and Code primers & Sequences & $\begin{array}{l}\text { Amplified } \\
\text { product }(\mathrm{pb})\end{array}$ & References \\
\hline gag & $\begin{array}{l}\text { 5'CCCGATCAGGAGCCCTATATCCTTACGTG-3' } \\
\text { 5'-CGCAGCGGTAATGTCGCGATCTCGT-3' }\end{array}$ & 362 & Akiyoshi et al, 1998 \\
\hline pol & $\begin{array}{l}\text { 5'-GCTACAACCATTAGGAAAACTAAAAG-3' } \\
\text { 5'-AACCAGGACTGTATATCTTGATCAG-3' }\end{array}$ & 326 & Patience et al, 1997 \\
\hline $\begin{array}{l}\text { env-A } \\
\text { PL } 170 / 171\end{array}$ & 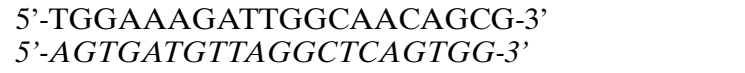 & 361 & Le Tissier et al, 1997 \\
\hline $\begin{array}{l}\text { env-C } \\
\text { PL 205/206 }\end{array}$ & 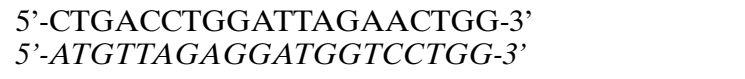 & 280 & Takeuchi et al, 1998 \\
\hline PERV Long & 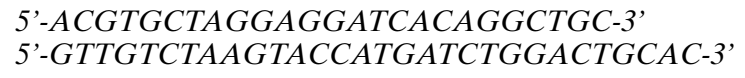 & 7200 & Bösch et al, 2000 \\
\hline $\begin{array}{l}\text { mt DNA } \\
\text { PMTF2/PMTR2 }\end{array}$ & $\begin{array}{l}\text { 5'-TCACCCATCATAGAAGAACTCCTACA-3', } \\
\text { 5'-TTTTACGGTTAAGGCTGGGTTATTAAT-3, }\end{array}$ & 255 & Switzer et al, 1999 \\
\hline
\end{tabular}

$1 \mathrm{mmol} / \mathrm{l}$ sodium pyruvate. 293 human embryonic kidney cells (CRL-1573), a PERV-susceptible cell line (provided by Dr N. Ferry, Nantes, France) were maintained in Dulbecco's modified Eagle's medium supplemented with $10 \%$ FCS and $2 \mathrm{mmol} / \mathrm{l}$ glutamine.

\section{Pig/human cell co-incubations}

Infection assays were done in 24-well plates (Costar, Cambridge, Mass., USA), using $2 \mathrm{ml}$ of culture medium. Non-irradiated pig islet cells or irradiated (120 Gray) PK15 or G2 cells $\left(3 \times 10^{5}\right.$ cells $)$ were co-incubated with $1.5 \times 10^{5}$ human cells for $48 \mathrm{~h}$. Cells were then centrifuged and cultured by sub-passaging twice a week. To enhance contacts between human and pig islet cells, co-incubations were also done with increasing numbers of pig cells and for a longer co-incubation time. Islet cells were co-incubated with human 293 cells or Jurkat cells at 10:1 or 100:1 ratios for 5 days. Cultures were always done in duplicate with different islet preparations. In some cases, a second co-incubation of human cells with new islet preparations was done two weeks after the first contact.

\section{Infection of human previously unexposed cells by PERV-infected human cells}

Human 293, Molt-4 or Jurkat cells, previously co-incubated with PK15 cells, were co-incubated with previously unexposed 293, Jurkat, Molt-4, Capan, or HT-29 cells. Virus-producing Molt-4 and Jurkat cells were irradiated with 10 Gray, and 293 cells received 100 Gray. The irradiation dosages were determined by $\left[{ }^{3} \mathrm{H}\right]$-thymidine incorporation to ensure that these "virus-producing" human cells died within 4 days after irradiation (data not shown).

\section{Monitoring of PERV infection on human cellular extracts}

DNA was extracted each week from $2 \times 10^{6}$ human cells using the QIAamp DNA blood mini-kit (Qiagen, Courtaboeuf, France). RNA was isolated from $10^{6}$ cells using the RNeasy mini-kit (Qiagen), and treatment with RNase-free DNase I (Roche Diagnostics) was done for $30 \mathrm{~min}$ at $37^{\circ} \mathrm{C}$ to avoid DNA contamination (the efficiency of this DNase treatment was assessed by RT-PCR completed without the RT step). The primers (Table 1) used for PCR amplification of PERV sequences (full-length PERV, pol, gag, env-A, env-B, env-C) or for pig-specific mitochondrial DNA (mt DNA) were synthesised by the Life Technologies system (Cergy Pontoise, France). PCR was done on GeneAmp PCR System 9700 (PE Applied Biosystems, Foster City, Calif., USA). Species-specificity of the primers was checked for the absence of signals on samples from human cells and their supernatants. Amplification products $(15 \mu \mathrm{l})$ were made visible using $2 \%$ agarose gels after ethidium bromide staining (Sigma, St. Louis, Mo., USA).

Detection of residual pig cellular DNA. PCR detection of a 255 bp sequence from the pig mt DNA cytochrome oxidase subunit II (COII), using primers PMTF2 and PMTR2 [36], was carried out to exclude the possibility that positive PERV PCR reactions on human cells co-incubated with pig cells were due to residual pig cellular DNA. The PCR was carried out with $0.75 \mu \mathrm{g}$ of DNA in $50 \mu \mathrm{l}$ reaction buffer $(10 \mathrm{mmol} / \mathrm{l}$ Tris- $\mathrm{HCl}, \mathrm{pH} 8.3$, $50 \mathrm{mmol} / 1 \mathrm{KCl}, 1.1 \mathrm{mmol} / \mathrm{l} \mathrm{MgCl}{ }_{2}, 0.01 \%$ gelatin), $200 \mu \mathrm{mol} / 1$ of each dNTP (Promega, Madison, Wis., USA), 2.5 U Red-Taq polymerase (Sigma, St. Louis, Mo., USA) and $0.5 \mu \mathrm{mol} / 1$ of each primer. The PCR conditions were: $94^{\circ} \mathrm{C}$ for $4 \mathrm{~min}, 94^{\circ} \mathrm{C}$ for $30 \mathrm{~s}$, annealing at $56^{\circ} \mathrm{C}$ for $30 \mathrm{~s}$, and $72^{\circ} \mathrm{C}$ for $30 \mathrm{~s}$ ( 40 cycles). A final elongation step was done at $72^{\circ} \mathrm{C}$ for $10 \mathrm{~min}$. Residual pig mt DNA was detected immediately after co-incubation, but finally disappeared (Fig. 2C) within 3 to 5 weeks, depending on the human cells used (Table 2).

Detection of PERV DNA by PCR. PCR were done as described above, except for the following points: firstly, $2 \mu \mathrm{g}$ of 
Table 2. Susceptibility of human cells to PERV infection after co-incubation with pig cells

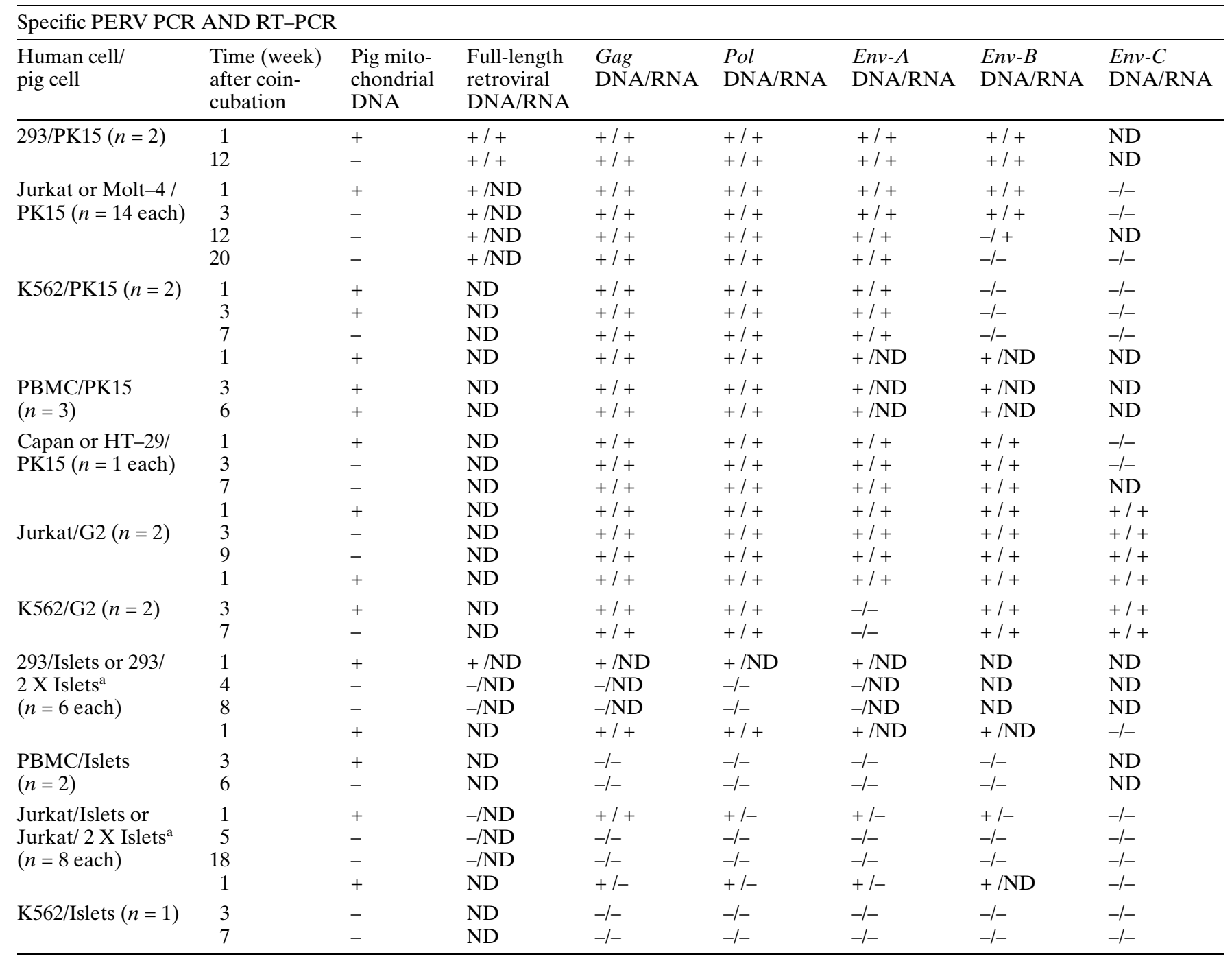

$N D$, not determined

${ }^{\text {a }}$ Human cells underwent two contacts with SPF pig islets

DNA were used; secondly, the annealing temperature was $56^{\circ} \mathrm{C}$ for pol and $g a g, 57^{\circ} \mathrm{C}$ for $e n v-A$ and $e n v-B$, and $63^{\circ} \mathrm{C}$ for $e n v-C$; and finally, the number of cycles was modified to 60,30 and 35 , respectively. To evaluate the sensitivity of PCR for $\mathrm{gag}$, pol, and $e n v$, DNA was extracted from mixtures of pig PK15 cells and human Jurkat cells $(n=3)$, and serial dilutions were obtained. PCR for gag, pol, env-A and $e n v-B$ were still positive with DNA dilutions corresponding to the equivalent of $0.1,1.0$, 0.15 and 0.3 PK15 cells, respectively, in the background of human DNA (Fig. 1A). During experiments with the same samples, PCR for pig COII mt DNA was found to be at least 40 times more sensitive than gag PCR, as it was still positive with $0.025 \mathrm{pg}$ DNA (vs $2.5 \mathrm{pg}$ for gag PCR). Simultaneously, real time quantitative COII and PERV gag PCR were done (GeneAmp 5700 sequence detection system, Applied Biosystem) and revealed that the above sensitivities corresponded to 5 and 200 detectable genes, respectively (data not shown).

Detection of PERV proviruses. Long PCR amplified a $7.2 \mathrm{~kb}$ fragment from all PERV sequences [18]. Amplification was done with the Platinum Taq High Fidelity system (Life Technologies).
Detection of PERV $m R N A$ by RT-PCR. Reverse transcription was carried out for $1 \mathrm{~h}$ at $42^{\circ} \mathrm{C}$ using $2 \mu \mathrm{g}$ of RNA in $80 \mu \mathrm{l} \mathrm{reac}$ tion buffer $(50 \mathrm{mmol} / \mathrm{l}$ Tris- $\mathrm{HCl}, \mathrm{pH} 8.3,75 \mathrm{mmol} / \mathrm{l} \mathrm{KCl}$, $3 \mathrm{mmol} / \mathrm{l} \mathrm{MgCl}$, $10 \mathrm{mmol} / \mathrm{l} \mathrm{DTT})$, with $400 \mathrm{U}$ of M-MLV-RT (Promega, Madison, Wis., USA), $1 \mathrm{mmol} / \mathrm{l}$ deoxynucleoside triphosphate (Promega), $40 \mathrm{U}$ of RNase inhibitor (Promega), and 0.04 U.D.O. of $\operatorname{pd}(\mathrm{N})_{6}$ (Pharmacia Biotech, Uppsala, Sweden). Thirteen microlitres of cDNA templates were amplified with $p o l, g a g, e n v-A, e n v-B$ or $e n v-C$ primers in the conditions described above. Control reactions with no reverse transcriptase were done to check for the absence of residual genomic DNA. For some experiments, PERV mRNA expression was compared between different situations, using semi-quantitative RT-PCR (Ambion Quantum RNA 18S Internal Standard kit (Clinisciences, Montrouge, France) [6]. Reverse transcription of pig islet RNA was carried out with the Sensiscript reverse transcriptase kit (QIAGEN).

Detection of full-length genomic PERV RNA. RNA were retrotranscribed with the Thermoscript RT-PCR system (Life Technologies). The resulting RNase H-treated cDNA was subjected to PCR with the Platinum Taq High Fidelity system 


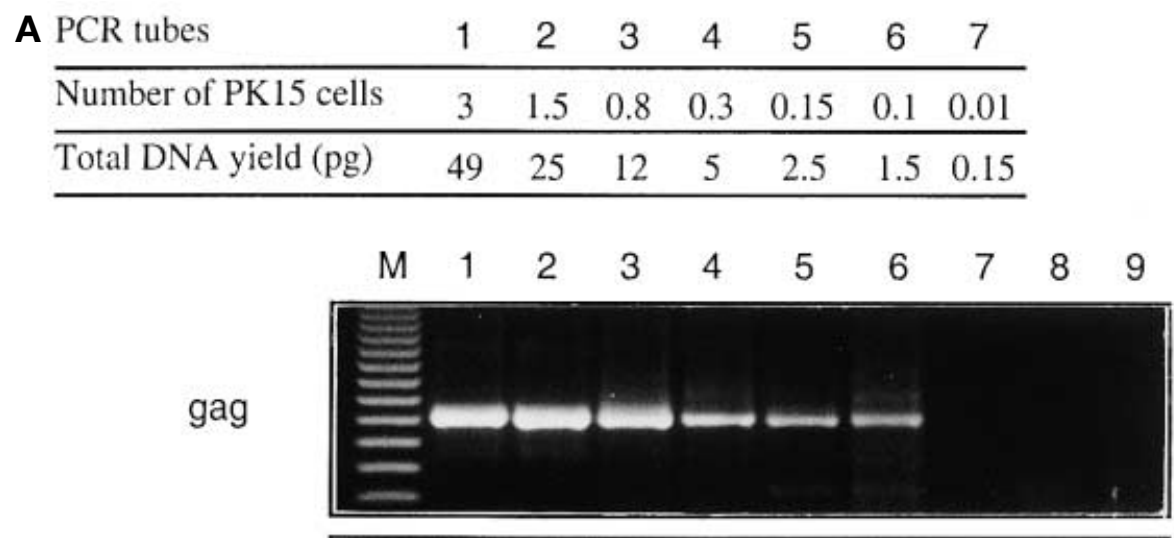

B
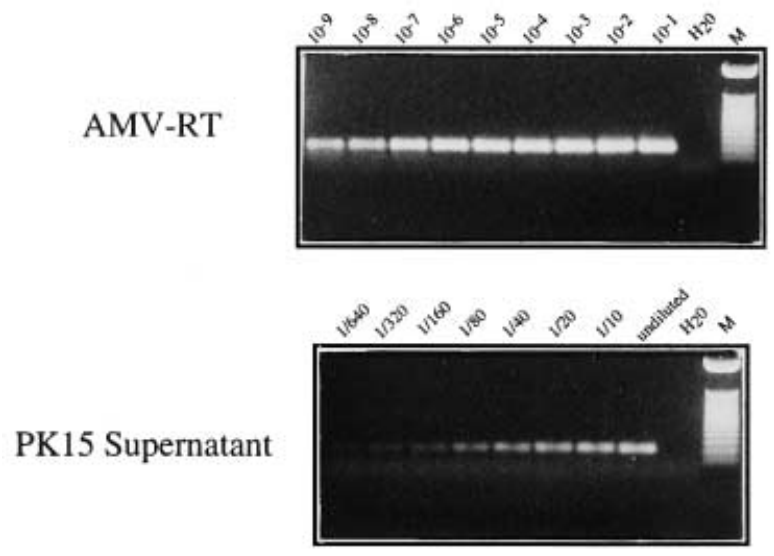

G2 Supernatant

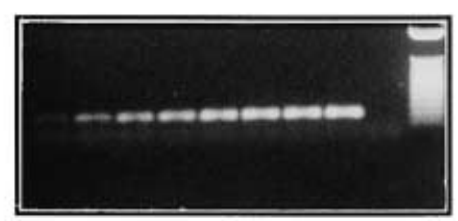

Fig 1. A Sensitivity of PCR detection of PERV DNA. The DNA concentration of a mixture of 50 PERV-producing PK15 pig cells and $2 \cdot 10^{6}$ human Jurkat cells was measured with UV spectrophotometry and then serially diluted. Lanes 1 through 7 are the corresponding gag and $e n v-B$ PCR results. Lane 8 is the DNA from Jurkat cells alone, and lane 9 is water. M: 50 bp DNA ladder. B Sensitivity of the PERT assay for detection of reverse transcriptase (RT) activity in cell culture supernatants. Top: serial dilution of AMV RT (from 0.1 to $10^{-9}$ units). Bottom: serial dilution of PK15 and G2 concentrated supernatants (from undiluted to 1:640 dilution). M: $50 \mathrm{bp}$ DNA ladder

(Life Technologies). Using the primers mentioned above, a 7.2 $\mathrm{kb}$ product and fragments of about $3 \mathrm{~kb}$ were produced.

Detection of pig circovirus (PCV) sequences by PCR or RT$P C R$ (Table 1). Under the PCR conditions previously described, a 530 bp fragment of PCV 1 was detected using a spe- cific primer pair [37], as well as a 493 bp fragment of PCV 2 [38]. Cells of a pig with postweaning multisystemic wasting syndrome, served as a positive control. The reverse-transcription step was performed with M-MLV-RT, as indicated above. To compare the sensitivity of PCR for PCV 1 and PERV gag, DNA was extracted from PK15 cells and serial dilutions were obtained. PCR for PCV 1 and PERV gag were still positive with $1 \mathrm{ng}$ and $2.5 \mathrm{pg}$ DNA, respectively (data not shown).

\section{Monitoring of PERV infection on human cell culture supernatants}

Detection of PERV $m R N A$ by RT-PCR. Supernatants were harvested every 2 weeks and filtered through $0.45-\mu \mathrm{m}$ filters. After ultracentrifugation of $10 \mathrm{ml}$ of supernatant (Beckman rotor SW 55, $100000 \mathrm{~g}$, for $90 \mathrm{~min}$ at $4{ }^{\circ} \mathrm{C}$ ), pellets were resuspended in $400 \mu \mathrm{l}$ of PBS and layered on a sucrose gradient (20-60\%) to purify the retroviral particles. After ultracentrifugation $\left(100000 \mathrm{~g}\right.$, for $3 \mathrm{~h}$ at $\left.4^{\circ} \mathrm{C}\right), 400 \mu \mathrm{l}$ fractions were serially 
Table 3. Susceptibility of PERV-infected human cells for the transmission of PERV sequences to previously unexposed human cells

\begin{tabular}{|c|c|c|c|c|c|c|c|}
\hline \multicolumn{8}{|c|}{ Specific PERV PCR AND RT-PCR } \\
\hline $\begin{array}{l}\text { Human cell/ } \\
\text { Human cell }\end{array}$ & $\begin{array}{l}\text { Time (week) } \\
\text { after coin- } \\
\text { cubation }\end{array}$ & $\begin{array}{l}\text { Full-length } \\
\text { retroviral } \\
\text { DNA/RNA }\end{array}$ & $\begin{array}{l}\text { Gag } \\
\text { DNA/RNA }\end{array}$ & $\begin{array}{l}P o l \\
\text { DNA/RNA }\end{array}$ & $\begin{array}{l}E n v-A \\
\text { DNA/RNA }\end{array}$ & $\begin{array}{l}E n v-B \\
\text { DNA/RNA }\end{array}$ & $\begin{array}{l}E n v-C \\
\text { DNA/RNA }\end{array}$ \\
\hline $\begin{array}{l}293 \text { or Jurkat / (293/PK15) } \\
(n=2 \text { each })\end{array}$ & $\begin{array}{r}2 \\
8 \\
12\end{array}$ & $\begin{array}{l}+1+ \\
+1+ \\
+1+\end{array}$ & $\begin{array}{l}+1+ \\
+1+ \\
+1+\end{array}$ & $\begin{array}{l}+1+ \\
+1+ \\
+1+\end{array}$ & $\begin{array}{l}+1+ \\
+1+ \\
+1+\end{array}$ & $\begin{array}{l}+1+ \\
+1+ \\
+1+\end{array}$ & $\begin{array}{l}\text { ND } \\
\text { ND } \\
\text { ND }\end{array}$ \\
\hline $\begin{array}{l}\text { Molt-4 or Jurkat / } \\
\text { (Molt-4/PK15) }(n=2 \text { each })\end{array}$ & $\begin{array}{l}1 \\
8\end{array}$ & $\begin{array}{l}\text { ND } \\
\text { ND }\end{array}$ & $\begin{array}{l}\mathrm{ND} /+ \\
-/-\end{array}$ & $\begin{array}{l}\text { ND } \\
-/-\end{array}$ & $\begin{array}{l}\mathrm{ND} /+ \\
\mathrm{ND}\end{array}$ & $\begin{array}{l}\mathrm{ND} /- \\
\mathrm{ND}\end{array}$ & $\begin{array}{l}\text { ND } \\
\text { ND }\end{array}$ \\
\hline
\end{tabular}

collected and evaluated $(5 \mu \mathrm{l})$ for the presence of sub-genomic and full-length PERV RNA, as well as pig $m t$ COII DNA, as described above.

Detection of RT activity (PERT assay). Supernatants were tested for $3 \mathrm{~h}$ at $37^{\circ} \mathrm{C}$ for their ability to produce reverse transcription of the RNA of bacteriophage MS2 (Roche Diagnostics) [15]. PCR amplification of cDNA was then done for 32 cycles using MS2 specific primers [39]. The sensitivity of the PERT assay was evaluated using serial dilutions of a commercial AMV reverse transcriptase $(n=3)$. This test detected $10^{-9}$ units of AMV-RT (Fig. 1B). Serial dilutions of concentrated supernatants showed that a 1:640 dilution of PK15 and G2 supernatants ( $n=2$ in each group) still gave positive results (Fig. 1B). Given the concentration factor of 30 during ultracentrifugation, these dilutions correspond to about $0.2 \mu \mathrm{l}$ of supernatants.

\section{Hybridisation analyses}

Products from long PCR and RT-PCR were transferred to Hybond-N + nylon membranes (Amersham Pharmacia Biotech, Orsay, France) by Southern blot transfer. Membranes were hybridised with alkaline phosphatase-labelled gag probes using the AlkPhos Direct Labelling and Detection systems (Amersham Pharmacia). After washes, membranes were incubated with the CDP-star ${ }^{\mathrm{TM}}$ chemiluminescent detection reagent and exposed to X-ray film (Amersham Paharmacia).

\section{Results}

PERV detection in SPF pig islet cells and pig cell lines. Long PCR amplified full-length DNA from all SPF pig islet preparations tested $(n=6)$, and from PERVproducing PK15 or G2 cells (data not shown). RTPCR allowed detection of PERV mRNA for gag, pol, env- $A$ and $e n v-B$ in PK15 $(n=24$, Fig. 2A) and G2 cells $(n=15$, data not shown). G2 cells also expressed $e n v-C$ mRNA. Full-length PERV RNA were detected in PK15 and G2 cells (data not shown). In contrast, PERV mRNA for gag, pol, and all three env sub-types (Fig. 2A) were found in pig islet cells, but no full-length PERV RNA was detected $(n=4)$. The intensity of product bands obtained for all PERV mRNA was reproducibly much lower in pig is- let cells than in PK15 or G2 cells, as already reported by us [6].

Full-length PERV RNA (long RT-PCR), PERV mRNA (RT-PCR) and RT activity (PERT) were detected in supernatants of PK15 $(n=12)$ and G2 $(n=15)$ cells (Table 4). In contrast, full-length PERV transcripts and RT activity were never detected in supernatants of pig islet cells $(n=10)$. However, 8 out of 10 pig islet cell supernatants tested were positive for $g a g$ mRNA, while 5 and 3 of them were also positive for $e n v-A$ and $e n v-B$, respectively (Table 4).

PK15 $(n=3), \mathrm{G} 2(n=3)$ and RPJ $(n=3)$ cells were positive for PCV1 DNA and mRNA (Fig. 2B), and negative for PCV2 sequences (data not shown). By contrast, DNA or mRNA for PCV1 or PCV2 sequences were not detected in the SPF pig tissues tested (kidney, heart and islets) or in a porcine aortic endothelial cell line ( $n=3$ for each).

Co-incubations of immune or non immune human cells with PERV-producing pig cells: PCR detection of PERV DNA in human cells. Gag, pol, env-A, env$B$ DNA, as well as full-length PERV inserts, were detected in 293 cells co-incubated with PK15 cells (293/ PK15) (Table 2).

Human immune cells co-incubated with PK15 cells (Jurkat/PK15, K-562/PK15) were positive for gag, pol and $e n v-A$ DNA throughout the long-term testing period (up to 20 weeks) (Table 2 and Fig.2C). Env-B DNA signals disappeared from Jurkat/PK15 at 12 weeks after co-incubation and were never detected in K-562/PK15. Molt-4/PK15 cells were positive for gag and pol DNA during the 20-week follow-up period, whereas $e n v-B$ and $e n v-A$ DNA disappeared after 3 and 12 weeks, respectively (Table 2). Env-C DNA was never detected in any human cells co-incubated with PK15 cells (Table 2 and Fig.2C). Fulllength PERV inserts were detected by long PCR in Jurkat/PK15 throughout the testing period (up to 20 weeks, Table 2). In accordance with env-specific PCR, full-length PERV contained only env-A sequences. Full-length PERV signals and $e n v-A$ sequences disappeared after 12 weeks in Molt-4/PK15 (Table 2). K-562 or Jurkat cells, when confronted 
A

PERVmRNA

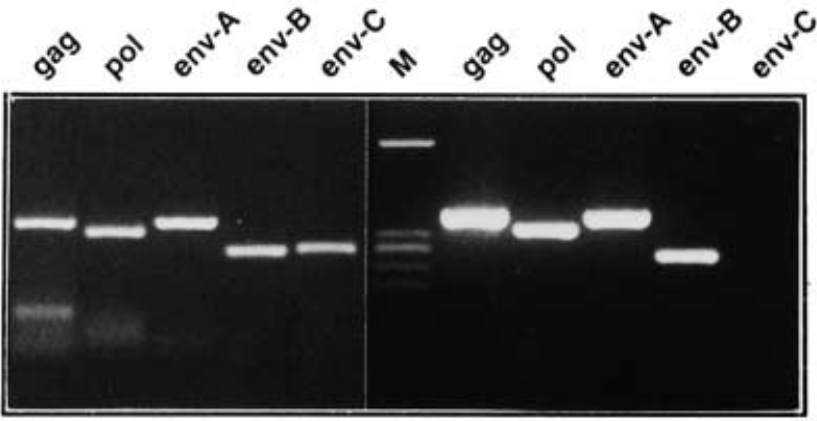

SPF pig islets PK15 cells

C

K562/G2

K562/PK15

K562/islets

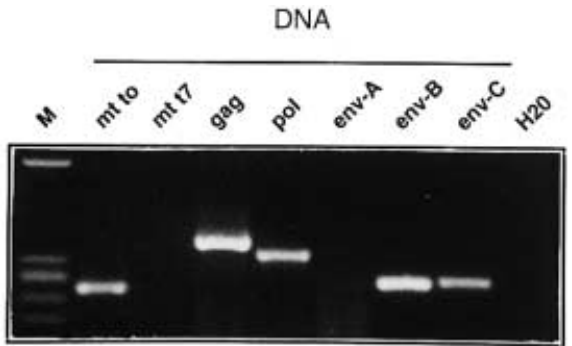

Molt-4/PK15
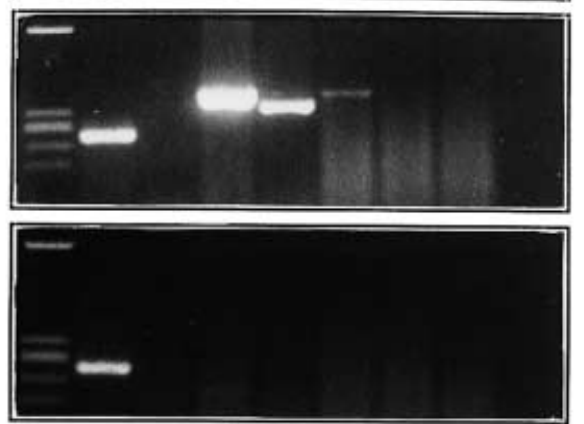

DNA

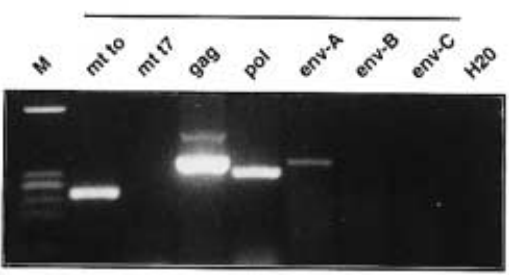

Jurkat/PK15

Jurkat/islets
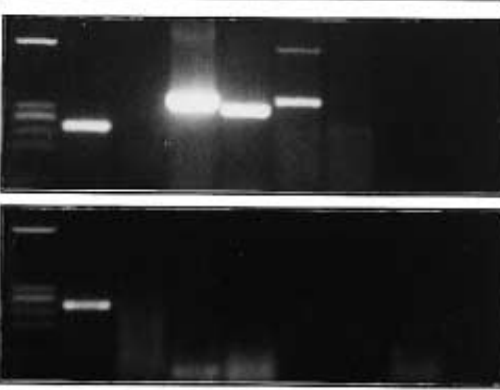

Jurkat/islets*
B

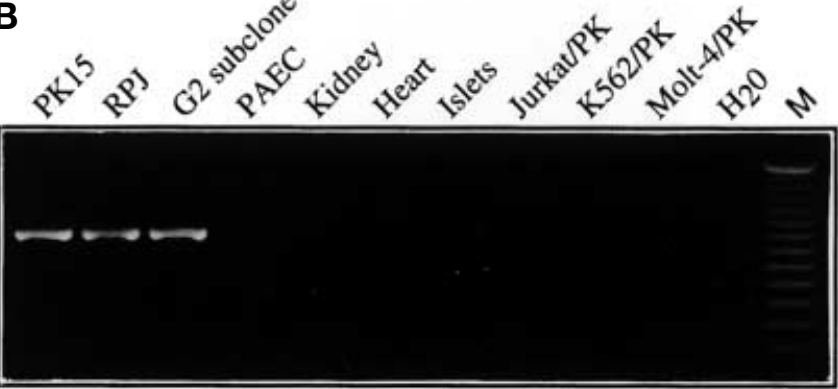

D

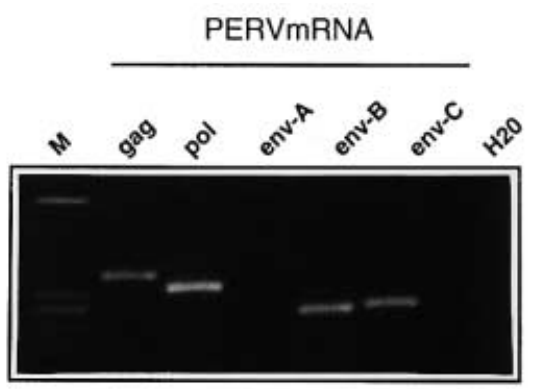

K562/PK15

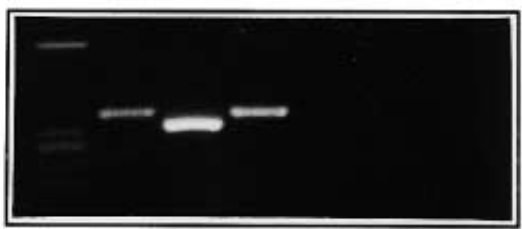

K562/islets

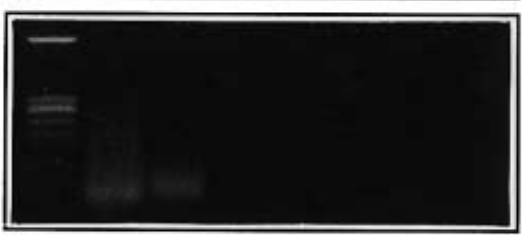

PERVmRNA

Molt-4/PK15

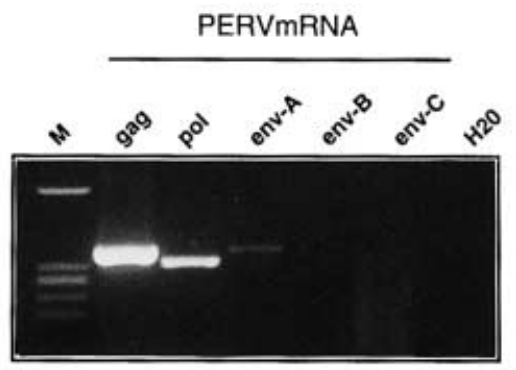

Jurkat/PK15

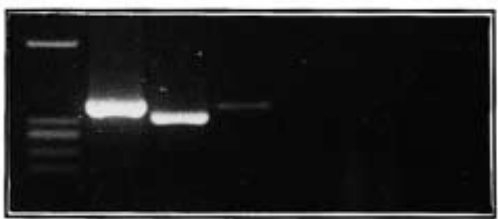

Jurkat/islets

Jurkat/islets*

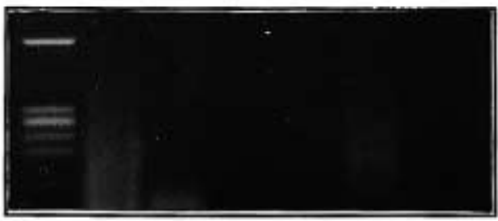

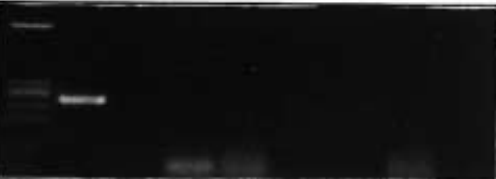

Jurkatislets 
with G2 pig cells, were positive for gag, pol, env-B and $e n v-C$ DNA during the 7-week follow-up period. Env-A sequences were detected in Jurkat, but not in K-562 samples (Table 2 and Fig. 2C).

PERV PCR also revealed the presence of $\mathrm{gag}, \mathrm{pol}$, $e n v-A$ and $e n v-B$ DNA during the 7-week follow-up of non immune Capan and HT-29 cells co-incubated with PK15 cells (Table 2). PERV sequences were also detected by PCR in human PBMC co-incubated with PK15 cells, from the end of co-culture to the 6th week of follow-up (Table 2).

RT-PCR detection of PERV RNA in human cells. $G a g$, pol, env- $A$ and $e n v-B$ mRNA, as well as fulllength PERV transcripts, were detected in 293 cells co-incubated with PK15 cells (Table 2). Gag and pol mRNA were also detected throughout the follow-up period in Jurkat, K-562 and Molt-4 cells coincubated with PK15 or G2 cells (Table 2 and Fig.2D). Consistently with PERV DNA detection, RT-PCR mainly revealed $e n v-A$ mRNA in Jurkat, $\mathrm{K}-562$ and Molt- 4 cells, while env- $C$ was never detected (Fig. 2D). When these human cells were exposed to $\mathrm{G} 2$ cells, they displayed $e n v-C$ products, in addition to $e n v-A$ and $e n v-B$ (Table 2). Capan/ PK15 and HT-29/PK15 also displayed gag, pol, and env RNA during the 7-week follow-up (Table 2). PERV mRNA were also detected in human PBMC co-incubated with PK15 cells (Table 2). No PCV1 sequences were detected in Jurkat, Molt-4, or K562 cells $(n=6$ each, Fig. 2B) after co-incubation with PK15 cells.

Release of PERV in supernatants of human target cells. Full-length PERV RNA (RT-PCR) and RT activity (PERT), but no residual pig $m t$ COII DNA, were detected in supernatants of 293 cells from 4 to 12 weeks after co-incubation with PK15 cells (Ta-

Fig 2. Representative PCR experiments. A Detection of PERV mRNA ( $g a g$, pol, env-A, B and C) by RT-PCR in PK15 cells and SPF pig islets. B RT-PCR detection of PCV-1 sequences. Lanes 1 to 7 were obtained with RNA from pig PK15, RPJ, G2 pig cell lines, porcine aortic endothelial cell line (PAEC), kidney, heart and pancreatic islets, respectively. Lanes 8 to 10 correspond to RNA from human Jurkat, K-562 or Molt- 4 cells co-incubated with pig PK15 cells. C Results of PCR for pig mitochondrial DNA and PERV DNA in human K-562, Jurkat, and Molt-4 cells co-incubated with G2 cells, PK15 cells, or SPF pig islets. "Mt to" and "mt $\mathrm{t} 7$ " indicate mitochondrial DNA signals at the end of co-incubation or seven weeks later, respectively. Specific PERV DNA signals correspond to samples obtained 7 weeks after co-incubation. D Results of RT-PCR on samples obtained 7 weeks after co-incubation of human cells with pig cells (corresponding to C). Asterisks indicate the results obtained with human Jurkat cells after two sequential co-incubations with pig islets. M: PhiX 174 DNA/Hae III markers, 50 bp DNA ladder; H2O: water as negative control ble 4). In contrast, no RT activity was found in supernatants of K-562, Molt-4, Jurkat, Capan or HT29 cells co-incubated with PK15 or G2 cells (Table 4). Supernatants of Jurkat or Molt-4 cells co-incubated with PK15 cells gave positive RT-PCR signals for sub-genomic mRNA and full-length genomic RNA during several weeks, but became negative from 12 weeks after co-incubation (Table 4). Env-B mRNA was never detected in supernatants of Molt-4/PK15 (Table 4). Gag, pol, env-A and env-B mRNA were detected in supernatants of Capan and HT-29 cells co-incubated with PK15 cells (Table 4). Env-C mRNA was also detected in supernatants of Jurkat cells co-incubated with G2 cells (Table 4).

Ability of PERV-infected human cells to transmit $P E R V$ sequences to "naive" cells. Irradiated human cells, previously PERV-infected by exposure to PK15 cells, were co-incubated with "naive" human cells. Naive 293 or Jurkat cells exposed to infected 293 cells became positive for full-length PERV DNA and RNA throughout the 12-week follow-up period (Table 3). Their supernatants became positive for full-length PERV RNA and RT activity, after 2 weeks (Table 4).

In contrast, Jurkat or Molt-4 cells exposed to PERV-infected Jurkat or Molt-4 cells were only transiently positive for gag, pol or env mRNA, but became negative after 2 weeks and throughout the 8week follow-up period (Table 3). No PERV DNA or mRNA were detected in Capan or HT-29 cells after co-incubation with infected Molt-4 or Jurkat cells (data not shown).

Absence of infection of human cells after co-incubation with SPF pig islet cells. Co-incubations of human cells with six islet cell preparations from different SPF pigs were carried out. PERV DNA sequences (gag, pol, env-A and $e n v-B$ ) were detected in all cells (293, Jurkat, K-562 and PBMC) from 1 to 3 weeks after co-incubation with pig islet cells (Table 2). Fulllength PERV inserts were also detected in 293 cells during the first 3 weeks after co-incubation with pig islet cells (Table 2). During the same 3-week period, porcine mt DNA was also detectable on cellular extracts by porcine specific mitochondrial PCR (Table 2 and Fig. 2C).

From 3 weeks after co-incubation with pig islet cells, porcine mt DNA became undetectable in human cells (Table 2). Simultaneously, PERV DNA and full-length PERV sequences disappeared in all human cell lines, including highly PERV-susceptible 293 cells (Table 2 and Fig. 2C). PERV gag, pol, or env mRNA could not be detected with RT-PCR in the different cell lines. The human cells remained negative for PERV when the pig islet to human cell ratio was increased to $10: 1$ and 100:1 and co-incuba- 
Table 4. Detection of PERV RNA by RT-PCR and RT activity by PERT assay in culture supernatants of human and pig cells, either alone or after co-incubations

\begin{tabular}{|c|c|c|c|c|c|c|c|c|c|}
\hline \multicolumn{10}{|l|}{ PERV RNA } \\
\hline Human cell/pig cell & $\begin{array}{l}\text { Time (week) } \\
\text { after coin- } \\
\text { cubation }\end{array}$ & $18 \mathrm{~S}$ rRNA & Gag & $E n v-A$ & Env-B & Env-C & $\begin{array}{l}\text { Genome } \\
\text { full-length } \\
\text { RNA }\end{array}$ & RT activity & pig mt COII \\
\hline 293/PK15 $(n=2)$ & $\begin{array}{r}4 \\
12\end{array}$ & $\begin{array}{l}\text { ND } \\
\text { ND }\end{array}$ & $\begin{array}{l}\text { ND } \\
\text { ND }\end{array}$ & $\begin{array}{l}\text { ND } \\
\text { ND }\end{array}$ & $\begin{array}{l}\text { ND } \\
\text { ND }\end{array}$ & $\begin{array}{l}\text { ND } \\
\text { ND }\end{array}$ & $\begin{array}{l}+ \\
+\end{array}$ & $\begin{array}{l}+ \\
+\end{array}$ & $\begin{array}{l}- \\
-\end{array}$ \\
\hline $\begin{array}{l}293 \text { or Jurkat / } \\
(293 / \mathrm{PK} 15)(n=2 \text { each })\end{array}$ & $\begin{array}{r}2 \\
12 \\
6\end{array}$ & $\begin{array}{l}\text { ND } \\
\text { ND } \\
+\end{array}$ & $\begin{array}{l}\text { ND } \\
\text { ND } \\
+\end{array}$ & $\begin{array}{l}\text { ND } \\
\text { ND } \\
+\end{array}$ & $\begin{array}{l}\text { ND } \\
\text { ND } \\
+\end{array}$ & $\begin{array}{l}\text { ND } \\
\text { ND } \\
\text { ND }\end{array}$ & $\begin{array}{l}+ \\
+ \\
+\end{array}$ & $\begin{array}{l}+ \\
+ \\
-\end{array}$ & $\begin{array}{l}- \\
- \\
-\end{array}$ \\
\hline Jurkat/PK15 $(n=14)$ & $\begin{array}{r}12 \\
20 \\
6\end{array}$ & $\begin{array}{l}+ \\
- \\
+\end{array}$ & $\begin{array}{l}+ \\
- \\
+\end{array}$ & $\begin{array}{c}+ \\
- \\
+\end{array}$ & $\begin{array}{l}- \\
- \\
-\end{array}$ & $\begin{array}{l}\text { ND } \\
\text { ND } \\
\text { ND }\end{array}$ & $\begin{array}{l}\text { ND } \\
- \\
\text { ND }\end{array}$ & $\begin{array}{l}- \\
- \\
-\end{array}$ & $\begin{array}{l}- \\
- \\
-\end{array}$ \\
\hline $\begin{array}{l}\text { Capan or HT29 / PK15 } \\
(n=1 \text { each })\end{array}$ & 7 & + & + & + & + & ND & ND & - & - \\
\hline Jurkat/G2 $(n=2)$ & $\begin{array}{l}3 \\
6 \\
9\end{array}$ & $\begin{array}{l}+ \\
+ \\
+\end{array}$ & $\begin{array}{l}+ \\
+ \\
+\end{array}$ & $\begin{array}{l}+ \\
+ \\
+\end{array}$ & $\begin{array}{l}+ \\
+ \\
+\end{array}$ & $\begin{array}{l}+ \\
+ \\
+\end{array}$ & $\begin{array}{l}\text { ND } \\
\text { ND } \\
\text { ND }\end{array}$ & $\begin{array}{l}- \\
- \\
-\end{array}$ & $\begin{array}{l}- \\
- \\
-\end{array}$ \\
\hline $\begin{array}{l}\text { 293/Islets or } 293 / \text { Islets }^{\mathrm{b}} \\
(n=6 \text { each })\end{array}$ & $\begin{array}{r}2 \\
10\end{array}$ & $\begin{array}{l}+ \\
+\end{array}$ & - & $\begin{array}{l}- \\
-\end{array}$ & $\begin{array}{l}- \\
-\end{array}$ & - & - & - & $\begin{array}{l}\text { ND } \\
\text { ND }\end{array}$ \\
\hline $\begin{array}{l}\text { Jurkat/Islets or Jurkat/ } \\
\text { Islets }^{\mathrm{b}}(n=8 \text { each })\end{array}$ & $\begin{array}{r}2 \\
10\end{array}$ & $\begin{array}{l}+ \\
+\end{array}$ & $\begin{array}{l}- \\
-\end{array}$ & $\begin{array}{l}- \\
-\end{array}$ & $\begin{array}{l}- \\
-\end{array}$ & $\begin{array}{l}- \\
-\end{array}$ & - & $\begin{array}{l}- \\
-\end{array}$ & $\begin{array}{l}\text { ND } \\
\text { ND }\end{array}$ \\
\hline K562/Islets $(n=1)$ & $\begin{array}{l}4 \\
7\end{array}$ & $\begin{array}{l}+ \\
+\end{array}$ & $\begin{array}{l}- \\
-\end{array}$ & $\begin{array}{l}- \\
-\end{array}$ & $\begin{array}{l}- \\
-\end{array}$ & - & - & - & $\begin{array}{l}\text { ND } \\
\text { ND }\end{array}$ \\
\hline
\end{tabular}

${ }^{a}$ Numbers of positive RT-PCR samples are indicated in brackets

${ }^{\mathrm{b}}$ Human cells underwent two contacts with SPF pig islets $N D$, not determined

tion time extended from 2 to 5 days. Even after two sequential co-incubations with pig islet cells, 293 and Jurkat cells became negative for PERV DNA and full-length PERV inserts 2 weeks after the second contact (Table 2). Consistently, full-length genomic PERV RNA, gag, pol, env- $A$ or $e n v-B$ RNA, were not detected in supernatants of human cells co-incubated 2 to 10 weeks before with pig islet cells. No RT activity was detected in the same supernatants (Table 4).

\section{Discussion}

This study on the risk of infection by PERV used PCR tests designed to enhance sensitivity and detect the few PERV sequences that might be present in human cells after co-incubation with pig cells. However, detection of PERV sequences could be due to the presence of residual pig cells or passive release of sequences by lysed pig cells and could be misinterpreted as "true" infection of human cells. Caution was thus taken to avoid misinterpretation.
Experimental conditions (irradiation dose, cell number and pig to human cell ratio) were designed to limit lysis of pig cells. Very sensitive detection of pig mtDNA was done to exclude contamination by pig cell DNA (COII PCR was at least 40 times more sensitive than PERV PCR). Moreover, for a given pig and human cell co-incubation, several tests were done on samples recovered every 2 weeks during long-term follow-up. The long-standing presence of PERV sequences strongly suggested the occurrence of a true infection, especially as full-length sequences were also detected with long RT-PCR. To avoid misinterpretation of false-positive results, the possible transmission of porcine circoviruses to human cells was also studied for the first time. PCV1 is known to infect PK15 cells [40]. In our study, PCV-1 was present in PK15 cells, as well as in G2 and RPJ cells, but not in several SPF pig tissues. PCV-2 was not detected in SPF pig tissues or cell lines. No transmission of PCV-1 sequences from PK15 cells to human cells was detected, even though PCR for PCV 1 was less sensitive than PERV PCR. 
In these carefully designed conditions, we first studied the presence of PERV sequences in pig cell lines, and in SPF pig islet cells, which were then used in co-incubation tests. PCR and RT-PCR allowed detection of gag, pol, env-A and env-B (but not env-C) PERV DNA and RNA in the PK15 cell line. Our results also confirm our preliminary findings [6], indicating that $\mathrm{G} 2$ cells, which generate more PERV than PK15 cells [41], contain PERV-C as well as PERV-A and -B. Accordingly, only $e n v-A$ and $-B$ mRNA were detected on PK15 supernatants, whereas all three mRNA env sub-types were found in G2 supernatants. We found RT activity in supernatants of PK15 and G2 cells. Thus, PK15 and G2 cells expressed PERV sequences and produced retroviruses but $\mathrm{G} 2$ cells produced $e n v-C$ PERV particles in addition to PERV-A and PERV-B. Gag, pol, and the three env sub-type DNA and RNA, were detected in SPF pig islet cells. In addition, full-length PERV inserts were detected in pig islet cells for the first time. However, full-length PERV RNA was not detected in pig islet cells. Consistently, only sub-genomic PERV RNA (and no RT activity), was detected in supernatants of pig islet cells. Several hypotheses could account for this discrepancy. Firstly, because PERV mRNA expression was very low in pig islets, the potential release of complete virions could have been undetectable by the present assays. However, positive RT-PCR results for gag, pol and env, in supernatants, could indicate the passive release of PERV partial sequences (but not of complete virions) by pig islet cells (the presence of $18 \mathrm{~S}$ ribosomal RNA in these supernatants could be consistent with this hypothesis). Thus, pig islet cells express all PERV sequences, although it is not clear whether they produced complete PERV particles.

Co-incubations were done to evaluate whether islet PERV sequences could be transferred to human cells. Co-incubations of human 293 cells with PK15 or G2 PERV-producing pig cells were done as positive infection controls. Infection of human cells by PK15 cells has been described [11,19], whereas G2 cells have not yet been used for this purpose. PERV DNA and RNA were detected in all human cells after co-incubation with PK15 or G2 cells, which is in agreement with previous reports $[11,17,19,24]$. The disappearance of pig mtDNA excluded false-positive results and confirmed the presence of PERV sequences during long-term follow-up of human cells co-incubated with PK15 or G2 cells. All human immune cells displayed $e n v-A$ DNA and mRNA after co-incubation with PK15 cells. Some of these cell types (in particular, 293 cells) also contained env-B DNA and mRNA. This confirms that PK15 cells mainly transmit PERV-A to human cells, although some human cells could also be sensitive to PERV-B $[19,24]$. Env-C sequences were never detected in human cells, which is consistent with their absence in
PK15 cells [19]. Our study also provides the first description of the infection of human cells by PERV from G2 cells. All PERV DNA and RNA (gag, pol, $e n v-A$, env- $B$, and also $e n v-C$ ) were detected in Jurkat cells after co-incubation with G2 cells. This suggests that Jurkat cells were also sensitive to infection by PERV-C. This confirms earlier results showing that pig aortic endothelial cells transmitted the three env sequences to the human 293 cell line [19]. This study included long-term and frequent follow-up of human cells, which allowed long-term detection of full-length PERV and $e n v-A$ sequences (up to 20 weeks after co-incubation, for the Jurkat/PK15 tests). In contrast to their stable integration, Molt-4 cells lost their full-length PERV inserts and env- $A$ sequences, and Jurkat cells lost their env-B sequences, after 12 weeks. These results suggest that some human cells could eliminate integrated PERV sequences, for example, through recombination between the LTR of proviruses [42].

Our study also included long-term analysis of PERV sequences in supernatants from human cells after co-incubation with pig cells. In agreement with other studies [11], our analyses confirmed a productive infection of the 293 cells by retroviruses from PK15 cells, as full-length PERV RNA and RT activity were detected, in the absence of residual pig $\mathrm{mt}$ DNA, in their supernatants. In addition, this analysis of PERV sequences in supernatants confirmed the results obtained on cells. Gag, pol, env-A, env-B, but not $e n v-C$, sequences were detected in supernatants of human cells co-incubated with PK15 cells. Conversely, all PERV sequences, including env-C, were detected in supernatants of Jurkat cells co-incubated with G2 cells, confirming that Jurkat cells were also sensitive to PERV-C. Our long-term analysis showed that $e n v-A$ and $e n v-B$ tended to disappear in supernatants of these cells. Thus, the concomitant analysis of cells and supernatants suggest that PERV, after a certain time, might no longer be released (or insufficiently released to be detected) by some human cells, even though persisting in their genome. Despite detection of PERV RNA for several weeks in supernatants of Jurkat and Molt-4 cells co-incubated with PK15 or G2 cells, no RT activity could be detected. This discrepancy could be due in part to differences in sensitivity between PCR/RTPCR and PERT assays. Alternatively, it could be interpreted as non-productive infections, as already reported for Jurkat cells co-incubated with humanadapted PERV (i.e. sub-passaged on human 293 cells) [24].

To assess whether infected human cells could transmit PERV sequences to previously unexposed human cells, PERV-positive 293, Jurkat, or Molt-4 cells were co-incubated with a range of human cells. Even though no marker could differentiate true infection of the naive human cells from residual 
PERV DNA of the source human cells, the risk of misinterpretation was reduced by the experimental conditions (irradiation which limited lifetime of the source cells; adherence, or not, to plastic of the unexposed and source cells, depending on the cases, which allowed separation after co-incubation) and the long-standing presence, or disappearance, of PERV sequences after more than 20 culture passages. PERV produced by 293 cells could infect naive 293 cells, which is in agreement with a previous report [24]. In contrast, Jurkat and Molt-4 cells sharing PERV sequences were not able to infect Molt-4, Jurkat, Capan, or HT-29 cells, which is consistent with the absence of detectable RT activity in supernatants of Jurkat/PK15 and Molt-4/PK15 in our study and with a previous report indicating that PERV-infected Molt- 4 cells were not able to infect human PBMC [24]. This suggests that these infected human cell types could produce incomplete particles or virus expression too low to infect previously unexposed cells. However, Jurkat cells became productively infected when they were co-incubated with PERV-infected 293 cells, as full-length PERV RNA and RT activity were detected in supernatants of Jurkat/ (293/PK15) cells. PERV produced by 293/PK15 cells were thus more infectious for human cells (human adaptation) than PERV initially produced by PK15 cells, which is in agreement with a previous finding [24].

The fact that all controls for PERV infections by PK15 and G2 cells were positive, and that PCR-derived tests were sensitive enough, ensured reliable analysis of the co-incubation of human cells with pig islet cells. PCR and RT-PCR revealed PERV DNA or RNA as long as residual pig islet cells were still present in the human cell cultures, but frequent and long term analyses failed to reveal DNA or RNA for gag, pol, and the three env sub-types, in 293, K-562 or Jurkat cells after the disappearance of pig $\mathrm{mt}$ DNA sequences (i.e. when contamination by pig islet cells could be excluded). Consistently, no full-length PERV DNA or RNA were detected. It is noteworthy that PERV signals were always negative, even after experimental conditions were modified to enhance the probability of transmitting PERV sequences. The same negative results were obtained when the pig islet to human cell ratio was increased and co-culture time extended. In addition, even after two sequential co-incubations with pig islet cells, even the sensitive human 293 cells became negative for PERV DNA and full-length PERV inserts 2 weeks after the second contact. Consistently, no PERV sequences or RT activity were detected in supernatants of human cells co-incubated with pig islet cells. These results suggest that in the present experimental conditions pig islet cells could not transmit PERV sequences to the panel of human cells used. The absence of infection could not have been due to defi- cient islet viability, as the islet preparations used remained capable of reacting qualitatively and quantitatively to nutriments, hormones, and neuromediators [3]. The present results are in accordance with the failure of porcine foetal neuronal cells to release detectable PERV in supernatants and their inability to infect 293 cells [26]. This would seem to contradict a report indicating that islets from Landrace pigs produce PERV able to infect 293 cells [25]. Studies have also suggested possible PERV transmission in SCID mice after pig islet xenografts [25, 32], although contradictory results have been reported [33]. Several factors could account for this discrepancy between our study and the previous report [25]. The pig breeds used were different and PERV expression varies among breeds $[12,13,16]$. Moreover, SPF pigs were used in the present study. The culture conditions could also influence PERV expression: synthetic serum was used here instead of foetal calf serum. In addition, because the 293 cells used in the previous report were transfected with a neomycin resistance gene, it cannot be excluded, for example, that this transgene could have increased the sensitivity to PERV infection.

In conclusion, the present study suggests that SPF pig islet cells have very little probability of transmitting PERV to human cells in vitro. This is of interest for the potential graft of SPF pig islets in Type I (insulin-dependent) diabetes mellitus. However, the sensitivity of human cells to stable and productive infection by PERV from PERV-producing cell lines depends on the human cell type and human adaptation of PERV was observed. Further studies are needed to assess the real risk of PERV infection in vivo during pig islet grafts.

Acknowledgements. This work was supported by grants from the Pays de la Loire and Brittany regions. SPF pig tissues were obtained by collaboration with AFSSA (Ploufragan, France). The authors thank Dr E. Gouin for providing isolated pig islets and Mrs S. Pogu for her excellent technical support. The preliminary results of this study were presented during the annual meeting of the European Association for the study of Diabetes (EASD) held in Jerusalem on September 2000.

\section{References}

1. Groth CG (1994) Transplantation of porcine fetal pancreas to diabetic patients. Lancet 344: 1402-1404

2. Gouin E, Rivereau AS, Darquy S et al. (1997) Minimisation of microbial contamination for potential islet xenografts using specific pathogen-free pigs and a protected environment during tissue preparation. Diabetes Metab 23: 537-540

3. Gouin E, Rivereau AS, Duvivier V et al. (1997) Perifusion analysis of insulin secretion from specific pathogen-free largewhite pig islets shows satisfactory functional characteristics for xenografts in humans. Diabetes Metab 24: 208-214

4. Rivereau AS, You S, Lalain S, Gouin E, Sai P (1998) In vitro xenorecognition of adult pig pancreatic islet cells by spleno- 
cytes from nonobese diabetic or non-diabetes-prone mice. Transplantation 66: 633-638

5. You S, Gouin E, Saî P (1998) Lymphocytes from NOD mice fed with pig cells displayed modified proliferation and lowered aggressiveness in vitro against pig islets. Diabetologia 41: 955-962

6. Clémenceau B, Lalain S, Martignat L, Saï P (1999) Porcine endogenous retroviral mRNAs in pancreas and a panel of tissues from specific pathogen-free pigs. Diabetes Metab 25: 518-525

7. Lalain S, Chaillou L, Gouin E, Saï P (1999) Intensity and mechanisms of in vitro xenorecognition of adult pig pancreatic islet cells by CD 4 + and CD 8 + lymphocytes from type I diabetic or healthy subjects. Diabetologia 42: 330-335

8. You S, Rivereau AS, Gouin E, Saï P (2001) In vitro coincubation of pig islet cells with spleen cells from non obese diabetic mice causes decrease of insulin release during perifusion: involvement of non T-cell and T-cell-mediated xenogeneic mechanisms. Clin Exp Immunol 123: 1-8

9. Ericsson T, Oldmixon B, Blomberg J, Rosa M, Patience C, Andersson $\mathrm{G}$ (2001) Identification of novel porcine endogenous betaretrovirus sequence in miniature swine. J. Virol 15: 2765-2770

10. Patience C, Switzer WM, Takeuchi Y et al. (2001) Multiple groups of novel retroviral genomes in pigs and related species. J Virol 15: 2771-2775

11. Patience C, Takeuchi Y, Weiss RA (1997) Infection of human cells by an endogenous retrovirus of pigs. Nat Med 3: 282-286

12. Akiyoshi DE, Denaro M, Zhu H, Greenstein JL, Banerjee P, Fishman JA (1998) Identification of a full-length cDNA for an endogenous retrovirus of miniature swine. J Virol 72: 4503-4507

13. Rogel-Gaillard C, Bourgeaux N, Billault A, Vaiman M, Chardon P (1999) Contruction of swine BAC library : application to the characterization and mapping of porcine type $\mathrm{C}$ endoviral elements. Cytogenet Cell Genet 85: 205-211

14. Czauderna F, Fischer N, Boller K, Kurth R, Tonjes RR (2000) Establishment and characterization of molecular clones of porcine endogenous retroviruses replicating on human cells. J Virol 74: 4028-4038

15. Martignat L, Saï P, Jestin A (1998) Detection of porcine endogenous retrovirus : possible involvement in pig islet xenotransplantation. Diabetes Metab 24: 434-441

16. Le Tissier P, Stoye JP, Takeuchi Y, Patience C, Weiss RA (1997) Two sets of human-tropic pig retrovirus. Nature 389: 681-682

17. Wilson CA, Wong S, Muller J, Davidson CE, Rose TM, Burd P (1998) Type C retrovirus released from porcine primary peripheral blood mononuclear cells infects human cells. J Virol 72: 3082-3087

18. Bösch S, Arnauld C, Jestin A (2000) Study of full-length porcine endogenous retroviral genomes (PERVs) with envelope gene polymorphism in a specific-pathogen-free panel large white swine herd. J Virol 74: 8575-8581

19. Takeuchi Y, Patience C, Magre S et al. (1998) Host range and interference studies of three classes of pig endogenous retrovirus. J Virol 72: 9986-9991

20. Martin U, Kiessig V, Blusch JH et al. (1998) Expression of pig endogenous retrovirus by primary porcine endothelial cells and infection of human cells. Lancet 352: 692-694

21. Armstrong JA, Porterfield JS, De Madrid AT (1971) C-type virus particles in pig kidney cell lines. J Gen Virol 10: 195-198

22. Todaro GJ, Benveniste RE, Lieber MM, Sherr CJ (1974) Charactezisation of a type-C virus released from the porcine cell line PK(15). Virology 58: 65-74

23. Kaeffer B, Bottreau E, Phan Thanh L, Olivier M, Salmon H (1990) Histocompatible miniature boar model : selection of transformed cell lines of $\mathrm{B}$ and $\mathrm{T}$ lineages producing retrovirus. Int J Cancer 46: 481-488
24. Wilson C, Wong S, VanBrocklin M, Ferderspiel M (2000) Extended analysis of the in vitro tropism of porcine endogenous retrovirus. J Virol 74: 49-56

25. Van der Laan LJ, Lockey C, Griffeth BC et al. (2000) Infection by porcine endogenous retrovirus after islet xenotransplatation in SCID mice. Nature 407: 90-94

26. Dinsmore JH, Manhart C, Raineri R, Jacoby DB, Moore A (2000) No evidence for infection of human cells with porcine endogenous retrovirus (PERV) after exposure to porcine fetal neuronal cells. Transplantation 70: 1382-1389

27. Martin U, Steinhoff G, Kiessig V et al. (1998) Porcine endogenous retrovirus (PERV) was not transmitted from transplanted porcine endothelial cells to babouns in vivo. Transpl Int 11: 247-251

28. Heneine W, Tibell A, Switzer WM et al. (1998) No evidence of infection with porcine endogenous retrovirus in recipients of porcine islet-cell xenografts. Lancet 352: 695-699

29. Patience C, Patton GS, Takeuchi Yet al. (1998) No evidence of pig DNA or retroviral infection in patients with short-term extracorporeal connection to pig kidneys. Lancet 352: 699-701

30. Paradis K, Langford G, Long Z et al. (1999) Search for crossspecies transmission of porcine endogenous retrovirus in patients treated with living pig tissue. Science 285: 1236-1241

31. Schumacher JM, Ellias SA, Palmer EP et al. (2000) Transplantation of embryonic porcine mesencephalic tissue in patients with PD. Neurology 54: 1042-1050

32. Deng YM, Tuch BE, Rawlinson WD (2000) Transmission of porcine endogenous retroviruses in severe combined immunodeficient mice xenotransplanted with fetal porcine pancreatic cells. Transplantation 70: 1010-1016

33. Elliot RB, Escobar L, Garkavenko O et al. (2000) No evidence of infection with porcine endogenous retrovirus in recipients of encapsulated porcine islet xenografts. Cell Transplant 9: 895-901

34. Weiser B, Nachman S, Tropper P et al. (1994) Quantification of human immunodeficiency virus type 1 during pregnancy: relationship of viral titer to mother-to-child transmission and stability of viral load. Proc Natl Acad Sci USA 91: 8037-8041

35. Arbet-Engels C, Darquy S, Capron F et al. (1994) A one-step, operator-independent method for isolating islets of Langerhans from the porcine pancreas. Artif Organs 18: 570-575

36. Switzer WM, Shanmugam V, Heneine W (1999) Polymerase chain reaction assays for the diagnosis of infection with the porcine endogenous retrovirus and the detection of pig cells in human and nonhuman recipients of pig xenografts. Transplantation 68: 183-188

37. Morozov I, Sirinarumitr T, Sorden D et al. (1998) Detection of a novel strain of porcine circoviruses in pigs with postweaning multisystemic wasting syndrome. J Clin Microbiol 36: 2535-2541

38. Ouardini M, Wilson L, Jetté R, Montpetit C, Dea S (1999) Multiplex PCR for detection and typing of porcine circoviruses. J Clin Microbiol 37: 3917-3924

39. Pyra H, Boni J, Schupbach J (1994) Ultrasensitive retrovirus detection by a reverse transcriptase assay based on product enhancement. Proc Natl Acad Sci USA 91: 1544-1548

40. Stevenson GW, Kiupel M, Mittal SK, Kanitz CL (1999) Ultrastructure of porcine circovirus in persistently infected PK15 cells. Vet Pathol 36: 368-378

41. Phan Thanh L, Kaeffer B, Bottreau E (1992) Porcine retrovirus: optimal conditions for its biochemical detection. Arch Virol 123: 255-265

42. Varmus HE, Quintrell NE, Ortiz S (1981) Retroviruses as mutagens: insertion and excision of a non-transforming provirus alters expression of a resident transforming provirus. Cell 25 : 23-26 